ARTIKEL BIMBINGAN DAN KONSELING

"KEGIATAN PENDUKUNG BIMBINGAN DAN KONSELING"

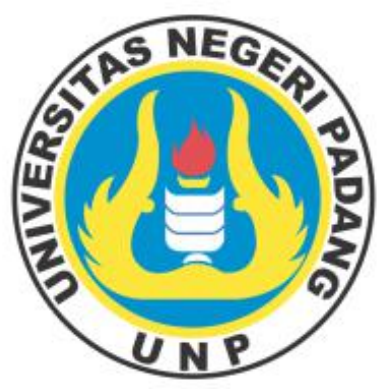

Oleh:

ELSA APRILLI

(19035014)

Dosen Pembimbing :

Dr. Yeni Karneli, M.Pd., Kons

UNIVERSITAS NEGERI PADANG

2021 


\section{KEGIATAN PENDUKUNG BIMBINGAN DAN KONSELING}

\section{A. Pendahuluan}

Kegiatan pendukung pada umumnya ditujukan secara langsung untuk memecahkan masalah klilen melainkan diperolehnya dan keterangan lain serta kemudahan atau komitmen yang membantu kelancaran dan keberhasilan kegiatan layanan terhadap klien. Kegiatan pendukung ini umumnya dilaksanakan tanpa kontak langsung dengan sasaran.

Kegiatan pendukung bimbingan dan konseling meliputi kegiatan aplikasi instrumen bimbingan dan konseling, himpunan data, kunjungan rumah, konferensi kasus, tampilan kepustakaan, dan alih tangan kasus. Semua jenis kegiatan pendukung dilaksanakan secara langsung, dikaitkan pada keempat bidang bimbingan serta disesuaikan dengan karakteristik dan kebutuhan klien. Hasil kegiatan pendukung dipakai untuk memperkuat satu atau beberapa jenis layanan bimbingan dan konseling.

\section{B. Kajian Teori}

Kegiatan pendukung adalah suatu kegiatan dalam pelayanan bimbingan dan konseling yang memungkinkan diperolehnya berbagai data, keterangan dan kemudahan bagi terlaksananya jenis-jenis layanan serta terwujudnya fungsi-fungsi BK.

Dalam BK saat ini ada enam kegiatan pendukung yaitu (a) aplikasi instrumentasi, (b) himpunan data, (c) kunjungan rumah, (d) konferensi kasus, (e) alih tangan dan (f) tampilan kepustakaan. Berikut uraiannya:

1. Aplikasi instrumentasi

Aplikasi instrumentasi merupakan kegiatan pendukung, dilaksanakan untuk mengumpulkan data dan keterangan tentang siswa keterangan tentang lingkungan siswa serta lingkungan yang lebih luas.

Pengumpulan data dapat dilakukan dengan berbagai instrumen, baik bentuk tes maupun non tes. Ada beberapa pertimbangan dalam penerapan instrumen BK seperti yang dikemukakan Prayitno (2004 : 316) sebagai berikut :

a. Instrumen haruslah sahih dan terandalkan

b. Konselor bertanggung jawab atas pemilihan instrumen yang akan dipakai 
c. Pemakaian instrumen harus dipersiapkan secara matang baik pada persiapan instrumennya maupun persiapan klien yang akan mengambil tes itu.

d. Pemahaman terhadap klien tidak hanya didasarkan atas data tunggal yang dihasilkan oleh tes, melainkan harus dilengkapi dengan data lain dari sumber-sumber relevan agar gambaran tentang klien lebih bersifat komprehensif.

e. Instrumen yang ada hanya sebagai alat bantu, oleh karena itu kekurangan atas ketiadaan instrumen hendaknya tidak menjadi penghambat bagi pelaksanaan BK.

2. Himpunan Data

Data tentang siswa sangat diperlukan dalam penyelenggaraan BK. Data yang sudah dikumpulkan baik melalui tes maupun non tes perlu disimpan di dalam himpunan data atau dikenal dengan cumulative record.

Ada beberapa jenis data yang perlu dikumpulkan oleh guru pembimbing, dari siswa seperti yang dikemukakan Prayitno (2004 : 320) sebagai berikut:
a. Identitas pribadi
b. Latar belakang keluarga
c. Kemampuan mental, bakat dan kondisi kepribadian
d. Sejarah pendidikan, hasil belajar, nilai mata pelajaran
e. Hasil tes diagnostik
f. Data kesehatan
g. Pengalaman ekstrakurikuler dan kegiatan di luar sekolah
h. Minat dan cita-cita pendidikan dan pekerjaan
i. Prestasi khusus yang pernah diperoleh

Selain data siswa diperlukan juga data tentang lingkungan. Data tentang lingkungan ini berguna dalam rangka memberi informasi dan penjelasan kepada siswa yang memerlukan informasi seperti informasi pendidikan. Data tentang lingkungan ini dapat berupa:

a. Data tentang informasi pendidikan meliputi jenis program, kurikulum sistem belajar dan sebagainya.

b. Data tentang informasi jabatan/pekerjaan, meliputi jenis-jenis jabatan, kesempatan dan syarat-syarat bekerja dan sebagainya.

c. Data tentang lingkungan sosial, meliputi adat istiadat, norma dan nilai-nilai lembaga/organisasi dan seterusnya. (Hallen, 2002 : 98) 
3. Kunjungan Rumah

Kunjungan rumah adalah kegiatan pendukung BK untuk memperoleh data keterangan serta kemudahan bagi terentaskan masalah siswa melalui kunjungan ke rumah siswa. Kunjungan rumah tidak dilakukan pada seluruh siswa tetapi hanya untuk siswa yang permasalahannya menyangkut dengan rumah atau orang tua.

Kegiatan kunjungan rumah menurut Prayitno (2004 : 424) memiliki tiga tujuan utama yaitu :

a. Memperoleh data tambahan tentang permasalahan siswa, khususnya yang bersangkut paut dengan keadaan rumah/orang tua.

b. Menyampaikan kepada orang tua tentang permasalahan anaknya

c. Membangun komitmen orang tua terhadap permasalahan anaknya

Ada beberapa hal yang perlu diperhatikan guru pembimbing berkenaan dengan kegiatan kunjungan rumah yaitu: 1) guru pembimbing menyampaikan perlunya kunjungan rumah kepada siswa yang bersangkutan, 2) menyusun rencana dan agenda yang konkrit dan menyampaikannya kepada orang tua dan kunjungan rumah tidak dapat dilakukan sebelum orang tua mengizinkannya.

4. Konferensi Kasus

Konferensi kasus adalah kegiatan pendukung BK untuk membahas permasalahan yang dialami siswa dalam suatu forum pertemuan yang dihadiri oleh berbagai pihak yang diharapkan dapat memberikan bahan, keterangan dan kemudahan bagi terentaskannya permasalahan siswa. Pertemuan dalam konferensi kasus bersifat terbatas dan tertutup.

Adapun tujuan dilaksanakannya konferensi kasus menurut Prayitno (2004 : 322) sebagai berikut :

a. Diperolehnya gambaran yang jelas, mendalam dan menyeluruh tentang permasalahan siswa.

b. Terkomunikasinya sejumlah aspek permasalahan kepada pihak-pihak yang berkepentingan dan bersangkutan, sehingga penanganan masalah itu menjadi lebih mudah dan tuntas

c. Terkoordinasinya penanganan masalah yang dimaksud sehingga upaya penanganan itu lebih efektif dan efisien.

5. Alih Tangan 
Alih tangan merupakan kegiatan pendukung untuk mendapatkan penanganan yang lebih cepat, tepat dan tuntas masalah yang dihadapi siswa dengan memindahkan penanganan kasus dari satu pihak ke pihak lainnya. Dalam permendikbud nomor 81 A menyebutkan bahwa alih tangan kasus yaitu kegiatan untuk memindahkan penanganan masalah peserta didik ke pihak lain sesuai keahlian dan kewenangan ahli yang dimaksud.

6. Tampilan Kepustakaan

Kegiatan Pendukung Tampilan Kepustakaan (PTK) merupakan "plus" dari "BK Pola 17". Tampilan kepustakaan ini dimaksudkan membantu permasalahan klien dengan cara memanfaatkan permasalahan klien dengan cara memanfaatkan pustaka, karena pustaka itu merupakan gudang ilmu yang terekam melalui buku, majalah, koran,tabloid, film. Berbagai uraian, penjelasan, cerita, ide, contoh dan bermacam-macam. Informasi sebagai hasil budaya manusia tersimpan di pustaka.

Semua yang ada pada pustaka dapat memperkuat dan memantapkan atau menjadi bahan perbandingan serta menambahan wawasan klien serta mempertajam analisis terhadap permasalahan klien. Tentang tampilan kepustakaan ini Prayitno (2006 : 2) mengemukakan sebagai berikut :

"Kegiatan pendukung tampilan kepustakaan (TKP) membantu klien dalam memperkaya dan memperkuat diri berkenaan dengan permasalahan yang dialami dan dibahas bersama konselor".

Adapun tujuan umum tampilan kepustakaan dalam rangka pelayanan konseling ialah :

a. Melengkapi substansi pelayanan konseling berupa bahan-bahan tertulis dan/atau rekaman lainnya yang ada dalam tampilan kepustakaan.

b. Mendorong klien memanfaatkan bahan-bahan yang ada dalam tampilan kepustakaan untuk memperkuat pengentasan masalah dan pengembangan.

C. Kesimpulan

Kegiatan pendukung bimbingan dan konseling ada enam, yaitu aplikasi instrumentasi gunanya untuk pengumpulan data dan keterangan peserta didik, keterangan tentang lingkungan peserta didik, dan lingkungan yang lebih luas baik tes maupun non tes. Himpunan data yang gunanya untuk menghimpun seluruh data dan keterangan yang relevan dengan keperluan pengembangan siswa dalam berbagai aspek. Kunjungan rumah yang gunanya untuk memperoleh pemahaman dan pengentasan dengan kunjungan rumah akan diperoleh berbagai data dan 
keterangan yang berhubungan dengan siswa. Konferensi kasus, gunanya mencari interprestasi yang tepat dan tindakan-tindakan konkret yang dapat di ambil. Tampilan kepustakaan, yaitu kegiatan menyediakan berbagai bahan pustaka yang dapat digunakan peserta didik dalam pengembangan pribadi, kemampuan sosial, kegiatan belajar, dan karir atau jabatan. Alih tangan kasus, bertujuan untuk mendapatkan penanganan yang lebih tepat dan tuntas dengan jalan memindahkan penanganan kasus dari pihak ke pihak yang lebih ahli. 


\section{DAFTAR PUSTAKA}

Suhertina. 2014. Dasar-Dasar Bimbingan dan Konseling. Pekanbaru: CV Mutiara Pesisir Sumatra

Prayitno. 2004. Dasar-Dasar Bimbingan dan Konseling. Jakarta: Rineka Cipta

Halen. 2002. Bimbingan dan Konseling. Jakarta: Ciputat Press 